\title{
Identification of focal ARDS using PF ratio: a cross-sectional study
}

Kay Choong See ${ }^{1,2^{*}}$ (D) Juliet Sahagun ${ }^{3}$ and Juvel Taculod ${ }^{3}$

Keywords: Diagnosis, Lung, Respiratory distress syndrome, Adult, Ultrasonography

In normal lungs, ventilation exceeds perfusion in lung areas above the heart while perfusion exceeds ventilation in lung areas below the heart (i.e., in the posterobasal lung areas when a person is supine) [1]. When the lung bases are diseased, perfusion exceeds ventilation more markedly, gas exchange within the affected alveoli gets diminished, the partial pressure of alveolar oxygen falls, and hypoxemia ensues. To mitigate this mismatch of perfusion and ventilation, hypoxic vasoconstriction occurs in areas of poorly ventilated lung.

However, hypoxic vasoconstriction is impaired in acute respiratory distress syndrome (ARDS) [2, 3]. As such, if consolidation exists predominantly in the posterobasal lung regions (i.e., focal ARDS) [4], we can expect that greater ventilation-perfusion mismatch could reduce oxygenation more severely, as measured using the partial pressure of arterial oxygen divided by fraction of inspired oxygen (PF ratio). If an association between focal ARDS and PF ratio can be shown, PF ratio could then be used in place of thoracic imaging to identify focal ARDS. We therefore hypothesized that focal ARDS is associated with lower PF ratio and investigated this relationship.

We included patients with ARDS fulfilling the Berlin Definition, who were admitted to our Medical Intensive Care Unit in 2014-2017, and who only received invasive mechanical ventilation. On admission, trained respiratory therapists performed a 12-point lung ultrasound using a $2-4 \mathrm{MHz}$ phased array transducer and semi-quantitatively scored each region [5]. We identified focal ARDS on lung ultrasound [6], if the consolidated regions were only

\footnotetext{
*Correspondence: kay_choong_see@nuhs.edu.sg

${ }^{1}$ Division of Respiratory \& Critical Care Medicine, Department of Medicine, National University Hospital, 1E Kent Ridge Road, NUHS Tower Block Level 10, Singapore 119228, Singapore

${ }^{2}$ Department of Medicine, Yong Loo Lin School of Medicine, National University of Singapore, Singapore, Singapore

Full list of author information is available at the end of the article
}

(C) The Author(s). 2020 Open Access This article is licensed under a Creative Commons Attribution 4.0 International License, which permits use, sharing, adaptation, distribution and reproduction in any medium or format, as long as you give appropriate credit to the original author(s) and the source, provide a link to the Creative Commons licence, and indicate if changes were made. The images or other third party material in this article are included in the article's Creative Commons licence, unless indicated otherwise in a credit line to the material. If material is not included in the article's Creative Commons licence and your intended use is not permitted by statutory regulation or exceeds the permitted use, you will need to obtain permission directly from the copyright holder. To view a copy of this licence, visit http://creativecommons.org/licenses/by/4.0/. The Creative Commons Public Domain Dedication waiver (http://creativecommons.org/publicdomain/zero/1.0/) applies to the data made available in this article, unless otherwise stated in a credit line to the data. 
Table 1 Predictors of focal ARDS

\begin{tabular}{|c|c|c|c|c|}
\hline & $N$ & Focal ARDS & OR $(95 \% \mathrm{Cl})$ & $\boldsymbol{P}$ value \\
\hline All patients & 152 & $16(10.3 \%)$ & NA & NA \\
\hline \multicolumn{5}{|l|}{ ARDS severity ${ }^{\mathrm{a}}$} \\
\hline Mild & 39 & $4(10.3 \%)^{b, c}$ & Reference & Reference \\
\hline Moderate & 62 & $4(6.5 \%)^{b, c}$ & $0.60(0.14-2.57)$ & 0.494 \\
\hline Severe & 51 & $8(15.7 \%)^{b, c}$ & $1.62(0.45-5.86)$ & 0.456 \\
\hline PF ratio $<150 \mathrm{mmHg}$ & 86 & $10(11.6 \%)$ & $1.32(0.45-3.83)$ & 0.614 \\
\hline PF ratio $(\mathrm{mmHg})$ & 152 & $16(10.3 \%)$ & $1.00(0.99-1.01)$ & 0.691 \\
\hline
\end{tabular}

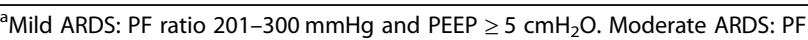
ratio $101-200 \mathrm{mmHg}$ and PEEP $\geq 5 \mathrm{cmH}_{2} \mathrm{O}$. Severe ARDS: PF ratio $\leq 100 \mathrm{mmHg}$ and PEEP $\geq 5 \mathrm{cmH}_{2} \mathrm{O}$

${ }^{\mathrm{b}}$ Fisher exact test, $P=0.275$

'Chi-square test for trend, $P=0.345$

ARDS acute respiratory distress syndrome, $\mathrm{Cl}$ confidence interval, NA not applicable, OR odds ratio, PEEP positive end-expiratory pressure, PF ratio partial pressure of oxygen in arterial blood divided by the inspired oxygen fraction

present in the posterobasal regions (combination of lower lateral, upper posterior, and lower posterior regions) and absent in the anteroapical regions (combination of upper anterior, lower anterior, and upper lateral regions) [4].

The association of focal ARDS with PF ratio was analyzed using logistic regression and with PF ratio (taken at the time of the lung ultrasound scan) as a continuous variable. To check for any nonlinear relationship of focal ARDS with PF ratio, we fitted a logistic regression model using a restricted cubic spline with four knots and taking the PF ratio of the first knot as the reference level. Wald test for linearity was then done $(P<0.05$ indicates nonlinearity).
One hundred fifty-two patients were studied (age $63.3 \pm 14.1$ years; 53 (34.9\%) female; ICU mortality 16.5\%; hospital mortality 33.6\%). Admission diagnoses were as follows: pneumonia (61 patients; $40.1 \%$ ), nonpneumonia sepsis $(19 ; 12.5 \%)$, chronic obstructive pulmonary disease $(9 ; 5.9 \%)$, acute myocardial infarction (3; $2.0 \%)$, stroke $(12 ; 7.9 \%)$, and other diagnoses such as massive hemoptysis, pulmonary vasculitis, and pneumonitis $(48 ; 32.6 \%)$. Median lung ultrasound scores (interquartile range) were generally worse in posterobasal regions compared to anteroapical ones: right posterobasal $3(0-6)$, left posterobasal $2.5(0-5)$, right anteroapical $0(0-3)$, and left anteroapical $2(0-$ 3). Mean PF ratio was $148 \pm 71 \mathrm{mmHg}$. PF ratio was not associated with focal ARDS (Table 1), and spline analysis did not suggest non-linearity (Fig. 1, Wald test $P=0.612$ ).

We found that PF ratio was not associated with focal ARDS. A possible reason could be that the degree of oxygenation impairment is related to the extent of lung involvement in ARDS, rather than the distribution of lung involvement. To illustrate using data from our patients, for every 1 point increase in total lung ultrasound score, PF ratio decreased by 1.7 (95\% CI -3.3 to $-0.19, P=0.028$ ). In the light of our results, thoracic imaging remains a requirement for identification of focal ARDS. Admittedly, our study is limited by a single-center cohort involving medical patients and using ultrasound as the sole modality for detailed lung imaging. Our findings should therefore be validated in external cohorts, in non-medical patients, and with computed tomography.

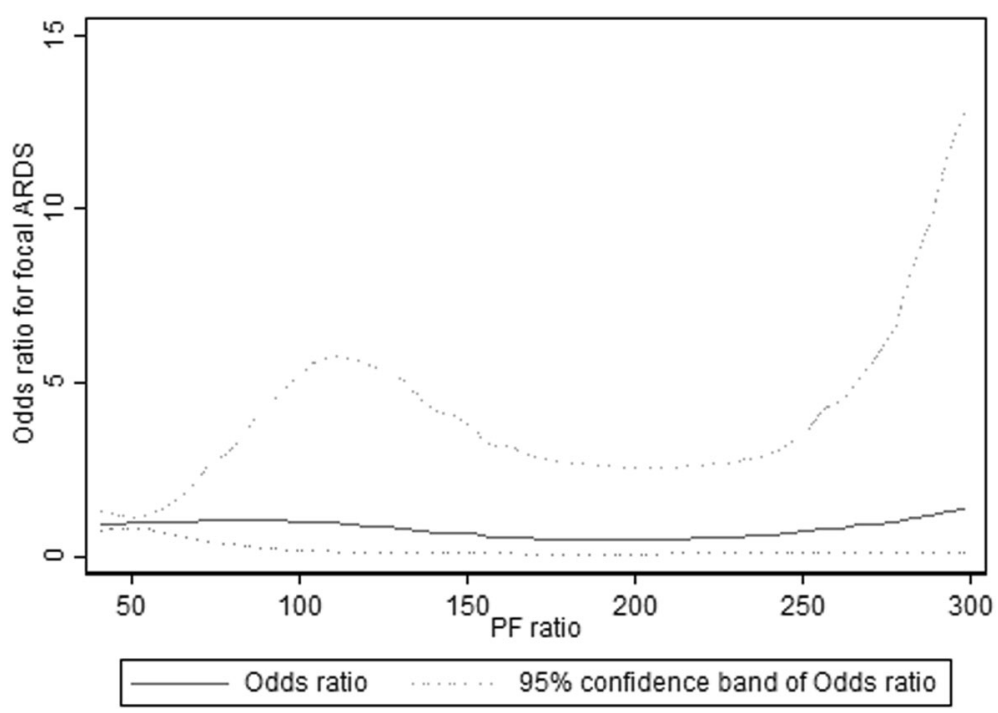

Fig. 1 Association of odds ratio for focal ARDS with PF ratio, using a restricted cubic spline with 4 knots 


\section{Abbreviations}

ARDS: Acute respiratory distress syndrome; PF ratio: Ratio of partial pressure of arterial oxygen divided by fraction of inspired oxygen

\section{Acknowledgements}

The authors would like to thank the physicians, nurses, and respiratory therapists who have cared for our patients.

\section{Authors' contributions}

$\mathrm{KCS}$, study concept, design, drafting of manuscript. All authors, study conduct, data analysis and interpretation, critical revision of the manuscript for important intellectual content. All authors had full access to all of the data in the study and take responsibility for the integrity of the data and the accuracy of the data analysis. The author(s) read and approved the final manuscript.

\section{Funding}

No funding was required for this study.

\section{Availability of data and materials}

The data that support the findings of this study are available from the corresponding author, KCS, upon reasonable request.

\section{Ethics approval and consent to participate}

Our Ethics Review Board (National Healthcare Group Domain-Specific Review Board) approved the study (approval number DSRB B/2013/00132). As the study is a retrospective observational one, the need for patient consent was waived.

\section{Consent for publication}

Not applicable.

\section{Competing interests}

KCS has received honoraria and travel support from Medtronic. JS and JT have no conflicts of interest to declare.

\section{Author details}

${ }^{1}$ Division of Respiratory \& Critical Care Medicine, Department of Medicine, National University Hospital, 1E Kent Ridge Road, NUHS Tower Block Level 10, Singapore 119228 , Singapore. ${ }^{2}$ Department of Medicine, Yong Loo Lin School of Medicine, National University of Singapore, Singapore, Singapore. ${ }^{3}$ Division of Critical Care - Respiratory Therapy, National University Hospital, Singapore, Singapore.

Received: 23 April 2020 Accepted: 20 July 2020

Published online: 29 July 2020

\section{References}

1. Glenny RW. Teaching ventilation/perfusion relationships in the lung. Adv Physiol Educ. 2008;32(3):192-5.

2. Johnson NJ, Luks AM, Glenny RW. Gas exchange in the prone posture. Respir Care. 2017:62(8):1097-110.

3. Rouby JJ, Puybasset L, Cluzel P, Richecoeur J, Lu Q, Grenier P. Regional distribution of gas and tissue in acute respiratory distress syndrome. II. Physiological correlations and definition of an ARDS Severity Score. CT Scan ARDS Study Group. Intensive Care Med. 2000;26(8):1046-56.

4. Constantin JM, Jabaudon M, Lefrant JY, Jaber S, Quenot JP, Langeron O, Ferrandiere M, Grelon F, Seguin P, Ichai C, et al. Personalised mechanical ventilation tailored to lung morphology versus low positive end-expiratory pressure for patients with acute respiratory distress syndrome in France (the LIVE study): a multicentre, single-blind, randomised controlled trial. Lancet Respir Med. 2019;7(10):870-80.

5. See KC, Ong V, Wong SH, Leanda R, Santos J, Taculod J, Phua J, Teoh CM. Lung ultrasound training: curriculum implementation and learning trajectory among respiratory therapists. Intensive Care Med. 2016;42(1):6371

6. Arbelot C, Ferrari F, Bouhemad B, Rouby JJ. Lung ultrasound in acute respiratory distress syndrome and acute lung injury. Curr Opin Crit Care. 2008;14(1):70-4.

\section{Publisher's Note}

Springer Nature remains neutral with regard to jurisdictional claims in published maps and institutional affiliations.

Ready to submit your research? Choose BMC and benefit from:

- fast, convenient online submission

- thorough peer review by experienced researchers in your field

- rapid publication on acceptance

- support for research data, including large and complex data types

- gold Open Access which fosters wider collaboration and increased citations - maximum visibility for your research: over $100 \mathrm{M}$ website views per year

At $\mathrm{BMC}$, research is always in progress.

Learn more biomedcentral.com/submissions 